TRP Uluslararası Türkçe Edebiyat Kültür Eğitim Dergisi Sayı: 4/2 2015 s. 826-836, TÜRKIYY

\title{
YRD. DOÇ. DR. HACER TOKYÜREK'İN ALTUN YARUK SUDUR IV. TEGZINCÇ ADLI ESERİ ÜZERİNE
}

\section{Melike UÇAR*}

\section{Yrd. Doç. Dr. Hacer Tokyürek’in Özgeçmişi ve Akademik çalışmaları:}

1980 yılında Adana'da doğdu. 2001 yılında Erciyes Üniversitesi, Fen-Edebiyat Fakültesi, Türk Dili ve Edebiyatı Bölümünden mezun oldu. 2005 yılında aynı bölümün Eski Türk Dili Bilim Dalında, Eski Türkçede (VIII-XIII yy.) Yardımcı Fiiller başlıklı yüksek lisans tezini, 2011 yılında Eski Uygur Türkçesinde Budizm ve Manihaizm Terimleri başlıklı doktora tezini tamamladi.

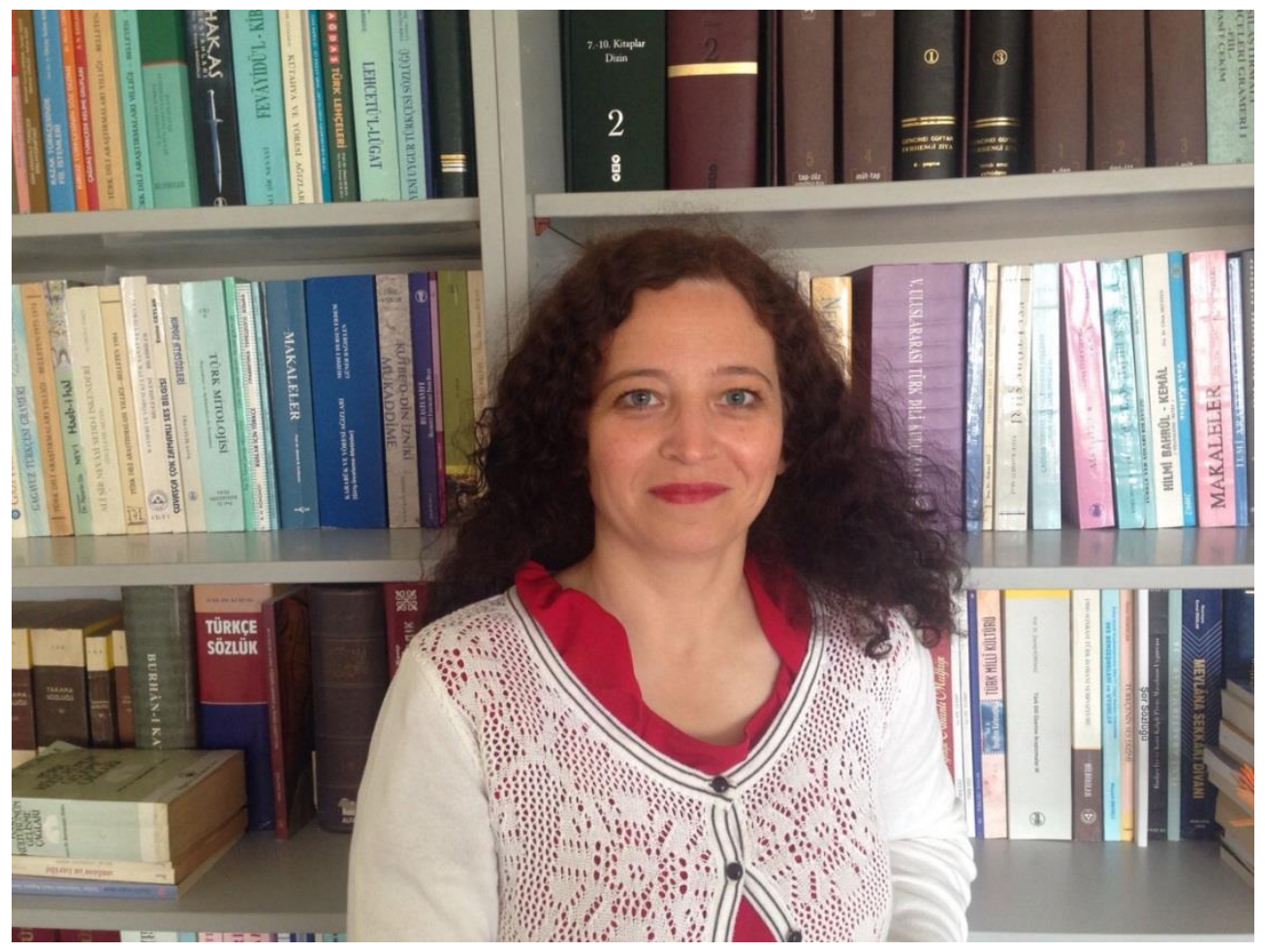

Yrd. Doç. Dr. Hacer Tokyürek'e ait bir görüntü

2001-2011 tarihleri arasında Millî Eğitim Bakanlığında öğretmen olarak çalıştı. 20112015 yılları arasında Nevşehir Hacı Bektaş Veli Üniversitesi, Fen-Edebiyat Fakültesi, Türk Dili ve Edebiyatı Bölümünde Yrd. Doç. Dr. olarak görev yaptı. Şu an Erciyes Üniversitesi, Edebiyat Fakültesi, Türk Dili ve Edebiyatı Bölümü, Eski Türk Dili bilim dalında Yrd. Doç. Dr. unvanıyla öğretim üyesi olarak çalışmaktadır.

\footnotetext{
*Arş. Gör.; Erciyes Üniversitesi, Edebiyat Fakültesi, Türk Dili ve Edebiyatı Bölümü, ucarmelike85@gmail.com.
} 
Yrd. Doç. Dr. Hacer TOKYÜREK'in bilimsel çalışmaları, Eski Uygur sahasında olup bu sahanın dili, kültürü, sosyolojisi ve dinî hakkında bilgiler veren yayınlardan meydana gelmektedir.

\section{Uluslararası hakemli dergilerde yayımlanan makaleler:}

TOKYÜREK, H. (2009). Eski Uygur Türkçesinde Ölüm Kavramı ile İlgili İfadeler. Bilig, 1(50), 169-198.

TOKYÜREK, H. (2012). Eski Uygurca Metinlere Göre Budizmin Manihaizme Etkisi. Turkish Studiesi, $7(4), 2888-2906$.

TOKYÜREK, H. (2013). Eski Uygur Türkçesinde Köyül Sözü. Bilig, 1(66), 247-272.

TOKYÜREK, H. (2013). Eski Uygurcada Hayvan Adları ve Bunların Kullanım Alanları. Türklük Bilimi Araştırmaları, 1(33), 221-281.

TOKYÜREK, H. (2014). Eski Uygurcada Āyurveda Tıbbı ve Beş Unsur. Türkiyat Mecmuası, 24, 235260.

TOKYÜREK, H., PEKACAR, Ç. (2014). Eski Türkçeden Günümüze Eksiz Ad Tamlaması Meselesi. Dil Araştırmaları, 15, 9-38.

TOKYÜREK, H. (2014). Eski Uygurca Sayı Sisteminde Takı ve Artokı Sözleri Üzerine. Türkbilig, 28, 112.

Uluslararası bilimsel toplantılarda sunulan ve bildiri kitaplarında (proceedings)

\section{basılan bildiriler:}

TOKYÜREK, H. (2013). Eski Uygurcada Dinî Terimlerde Yabancı Dillerin Gramatikal Etkisi Var Mıdır? VIII. Milletlerarası Türkoloji Kongresi, 2, 541-554.

\section{Yazılan ulusal / uluslararası kitaplar:}

TOKYÜREK, H. (2015). Altun Yaruk Sudur IV. Tegzinç (Karşılaştırmalı Metin Yayını). Kayseri: Laçin Yay.

\section{Ulusal bilimsel toplantılarda sunulan ve bildiri kitaplarında basılan bildiriler:}

TOKYÜREK, H. (2007). Eski Uygur Türkçesindeki Dinî Terimlerin İslami Literatüre Etkisi. Erciyes Üniversitesi Öğrenci Seтроzуити, 213-222.

TOKYÜREK, H. (2009). Eski Uygur Türkçesinde Benzetme Unsurları. Erciyes Üniversitesi Öğrenci Sетровуити, 247-257.

\section{Diğer yayınlar:}

TOKYÜREK, H., AYDIN E. (2012). Eski Türk Yer Adları, Eski Türk Yazıtlarına Göre Kömen Yayınları. Türkiyat Mecmuası, 22, 197-201.

TOKYÜREK, H. (2013). Eski Uygur Türkçesinde Hayvan Adları: Arslan. Türk Dilinin ve Edebiyatının Bugünkü Sorunlarl ve Çözümleri 2. Uluslararası Sempozyumu, 30 Mayls-1 Haziran 2013, İstanbul.

TOKYÜREK, H. (2013). Runik Türk Yazıtlarında ve Eski Uygur Metinlerinde Kadın Hiyerarşisi. Milletlerarası Eski Türk Yazıtları: Dil, Tarih ve Kültür Sempozyumu 25-28 Eylül 2013, Adiyaman.

TOKYÜREK, H. (2014). Eski Uygurca Manihaist Soğdca Tanrı Adları Üzerine. Milletlerarası SoğudTürk Münasebetleri Sempozyumu 21-23 Kasım 2014, İstanbul. 


\section{Yönetilen Tezler:}

\section{Yüksek Lisans:}

ERBAŞ, O. (2015), Nehcü'l-Feradis'te Kelime Grupları. Yayımlanmamış Yüksek Lisans Tezi, Nevşehir: Nevşehir Hacı Bektaş Veli Üniversitesi Sosyal Bilimler Enstitüsü.

\section{Projelerde Yaptığı Görevler:}

Eski Uygur Türkçesinde Budizm ve Manihaizm Terimleri, BAP, Araştırmacı, 2008-2011.

\section{2. İnceleme:}

Uygur Kağanlığı Kırgızlar tarafından yıkıldıktan sonra Uygurlar Moğolistan'dan güneye göç etmişlerdir. Yerleşik hayata geçen Uygurlar, daha çok çeviri eserlerine dayanan bir edebiyat meydana getirmişlerdir. Bu edebiyat dinî içeriği yoğun olup Budizm ve Manihaizm temelinde cereyan etmiştir. Eski Uygur Türkçesinin önemli ürünlerinden olan ve "Altın Işı1k" anlamına gelen Altun Yaruk Budizm'in öğretilerine ve Buda'nın menkıbelerine dayanmaktadır. Eserin ilk şekli Sanskritçe olup VII. yy.da Çinceye, X. yy.da Şinko Şeli Tutun tarafından Uygurcaya aktarılmıştır (Ölmez, 1991: 7). Uygur Türkçesine çevrilen en hacimli dinî metin olarak kabul edilen bu eser; Türkçe kelimeleri içerisinde çokça barındırmasından ötürü Türkoloji camiası açısından çalışmaları oldukça kıymetlidir.

Altun Yaruk Sudur IV. Tegzinç adlı eser giriş, Berlin metin parçaları, St. Petersburg (RM) asıl metin, Türkiye Türkçesine aktarım, açıklamalar ve dizin olmak üzere 6 ana bölümden ve 718 sayfadan oluşmaktadır.

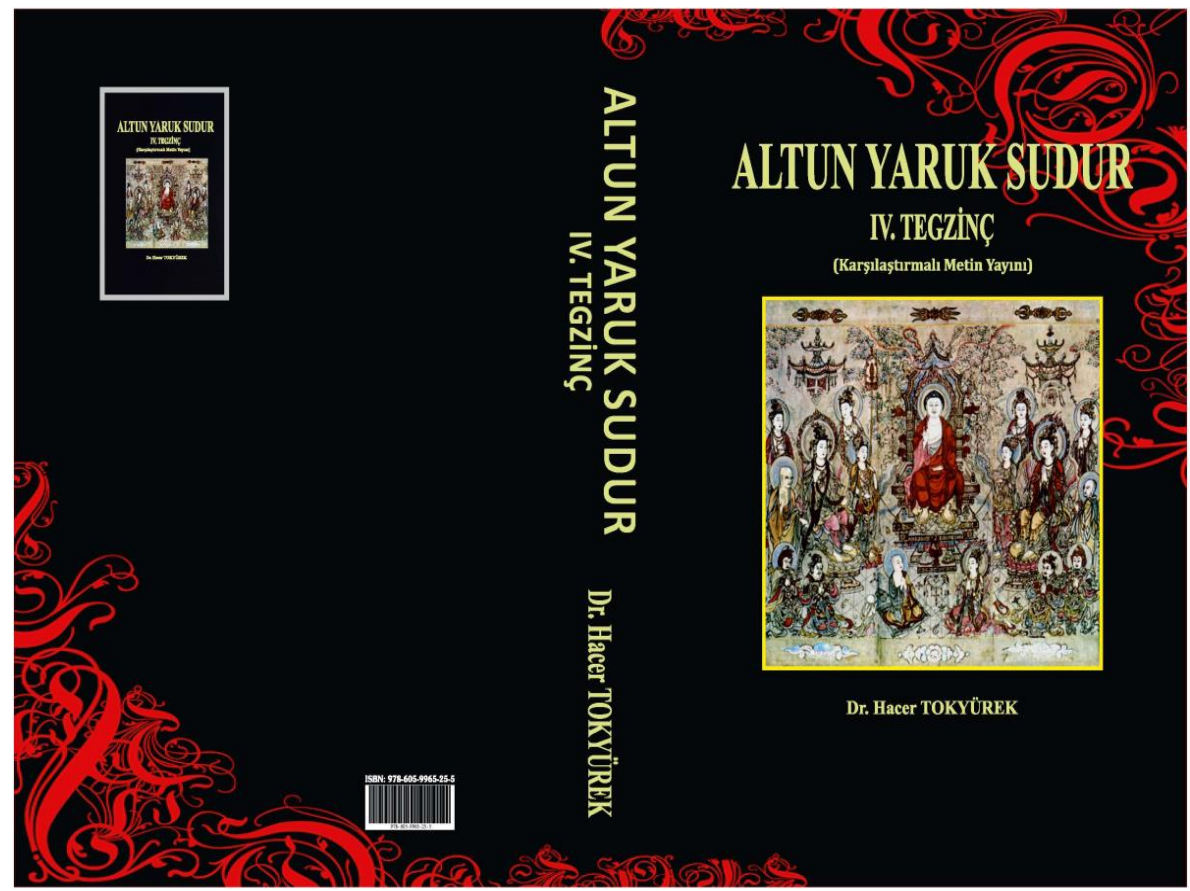

Yrd. Doç. Dr. Hacer TOKYÜREK'in Altun Yaruk Sudur IV. Tegzinç (Karşılaştırmalı Metin Yayını) adlı eserinin ön ve arka kapak görüntüsü 
Eserin Ön söz bölümünde (s. 5) Eski Uygur döneminin dinî ve felsefi yönünün ağır bastığ bir dönem olduğundan ve bu eseri çalışma nedenlerinden bahsedildikten sonra eserin bölümleri hakkında kısa bir tanıtım yapılmakta ve giriş bölümüne geçilmektedir.

Giriş bölümünde (s. 7-26) Altun Yaruk Sutra hakkında genel bir açıklama yapılmaktadır. Çin'in Gansu bölgesinde, Su-cou şehri yakınındaki Wun-fi-gu (Wun-şi-gu) adlı küçük bir köyün yakınlarında, Budistlere ait bir tapınakta ünlü Rus Türkoloğu Sergey Malov tarafından bulunan Altun Yaruk Sutra'nın Eski Uygur Türkçesi karş1lı̆̆ı altun öglüg y(a)ruk yaltrıklıg kopda kötrülmiš nom eligi ațl(ı)g nom bitig olduğu ifade edilir. Eserin Çinceden Uygurcaya Şinko Şeli Tutun tarafından X. yüzyılda çevrildiği belirtildikten sonra metnin Çincesi 金光明最勝王經 jīnguāngmíng zuìshèng wáng jīng şeklinde verilip “altın 1şıklı, parıltt11 en büyük öğreti (kitabı) hükümdarı" şeklinde açıklama yapılmıştır. Aslı Sanskritçe olan ve Budizmin en değerli yazmalarından olan bu eserin asıl adının Suvarnaprabhāsa-uttama-sūtraindra-rāja, Suvarṇaphāsottamasūtrrarāja, Suvarṇaprabhāsotta-ma olduğunu belirten yazar, asıl adında yer alan kelimeleri tek tek açıklayarak "altın 1şıklı her yere ulaşmış ya da her yeri fethetmiş öğreti hükümdarı"dır şeklinde bir tanımlama yapmaktadır. Çalışmada Altun Yaruk Sutra'nın Uygurca ve Çincesinin dışında Tibetçe, Japonca, Hotanca, Soğdca, Moğolca ve Tangutça tercümeleri de bulunduğu ifade edilmektedir. Uygurca Altun Yaruk çevirisi rahip Yì Jing çevirisine dayanmaktadır. Fakat Altun Yaruk metninin Ji-Ying çevirisi dışında başka bir çeviri ile bağlantılı olup olmadığı da tartışıldığının çünkü genel olarak Altun Yaruk metninin eldeki Çince metinden farklı olduğu görüldüğü belirtilmektedir. Böylece yazar, IV. kitapta, Çince metin ile Uygurca metin arasında farkl11ıkların olduğunu ve özellikle Altun Yaruk metninin [St.] Petersburg nüshası ile Berlin parçaları arasında önemli farklılıklar da bulunduğunu ispat etmeye çalışmaktadır. Yazar, [St.] Petersburg ve Berlin parçalarında yer alan iki cümleden hareket ederek ilk cümlenin Çincesi de mevcutken ikinci ifadenin Çincesinin olmadı̆̆ını, yine [St.] Petersburg nüshasında Türkçe sözlerin yanında Sanskritçeleri de kullanılırken Berlin parçalarında sadece Türkçeleri bulunduğunu gösterir. Bu durumu iki olasılık üzerinden değerlendiren yazar şu tespitlerde bulunmaktadır: İlk olasılık Altun Yaruk Sūtra tek bir metinden çevrilmediği, farklı zamanlarda farklı nüshalardan çevrildiğidir. Bu durum da Altun Yaruk Sutra Şinko Şeli Tutun tarafından X. yy.da çevrilmiş olmakla birlikte aynı eser daha sonraki dönemde başka bir nüshadan başka bir kişi tarafından tekrar çevrilmiş olabileceğini düşündürtmektedir. İkinci olasılık ise Sanskritçe kelimelerin sonradan müstensih tarafından da ilave edilmiş olmasıdır. Çünkü Türklerin İslamiyeti kabul etmelerinin ilk yı1larındaki Kur'an tercümelerinin daha sonraki dönemdeki Kur'an tercümeleri arasında önemli farkl11ıklar bulunması ve Karahanlı dönemi Kur'an tercümesindeki dinî terimlerin Arapça 
karş11lğı Türkçe verilmesine rağmen daha sonraki dönem Kuran tercümelerinde ise Farsça ve Arapça olarak gösterilmesi gibi Altun Yaruk Sutra için de aynı durumun geçerli olabileceğidir. Yazarın bu konudaki tespitleri Altun Yaruk'un tercümeleri hakkında fikir vermesi açısından önemlidir.

Giriş bölümünde IV. kitap ve içeriği hakkında da bilgi verilmiştir. Burada Uygurca Altun Yaruk Sutra'nın dördüncü kitap, altıncı bölümü eserin en uzun bölümü olduğu belirtilir. Uygurca arıg yer oronlar sayukı d(a)r(a)ni tegmä tutruk nomlarıg okıtmak atl(i)g altınč bölök törtinč tägzinč (0006-0009) ve Çince 最淨地陀羅尼。制譯。品第六。卷第四 zuì jìng de tuóluóní, zhì yì, pǐn dì liù, juăn dì sì "çok temiz yerdeki dhāraṇī denilen dizginlemek (adli) öğretileri (okutmak adlı) altıncı (bölüm), dördüncü kitap” şeklinde çeviri yapan yazar IV. kitabın altıncı bölümünün [St.] Petersburg nüshasında ya da Radlov-Malov ${ }^{1}$ baskısında 201-344 sayfaları arasında olduğunu toplamda 144 sayfadan meydana geldiğini ifade etmektedir. $\mathrm{Bu}$ bölümde kitap ve kitabın içeriği hakkında genel bilgi verilmektedir. Eserin Berlin parçalarının Ehlers ve Rashcmann tarafindan kataloglandığ 1 ve U ile kayıtlı 196, Mainz ile kayıtlı 62 ve toplamda ise 258 (arkalı önlü 516) parça bulunduğu ifade edilmektedir. IV. kitap, Siṃhadhvajāpratihataprabhaṃkara adlı Bodhisattva'nın Buddha'ya sorduğu çeşitli sorularla başlar ve bu bölüm soru cevap şeklinde devam eder. Tam bir sutra özelliği taşıdığı tespitinin yapıldığı eserde, dikkat çekici taraf dinî hikâyelerin yer almamasıdır. Herhangi bir olay örgüsünün bulunmadığı eserde Bodhisattvaların ya da canlıların yapması ya da yapmaması gereken kurallar, Pāramitā’lar (erdemler) anlatılmaktadır. Burada toplamda on Pāramitā'dan bahsedilir. Amaç Bodhisattvaların ya da canlıların Pāramitā'ları uygulamaları sonucunda muhteşem ya da tam bilgiyi elde etmeleridir.

Pāramitā ve Türleri (s. 9-15) başlığında, Pāramitā teriminin parama kökünden türemiş olduğu, "en yüksek, zirve, doğum ölüm kıyısı olan bu kıyıdan diğer kıyıya yani Nirvana'ya geçişi” temsil ettiği ifade edilir. Ayrıca Çincede bu terim canlıları ölümden kurtarmak ve çekilen eziyete bir son vermek için uygulanan prensipler olarak algılanmaktadır. Böylece canlıların bu prensipleri uygulamaları sonucunda bu kıyıdan kurtulup diğer kıyıa yani Nirvana'ya ulaşmaları sağlanacağı inanc1 benimsenmektedir. Pāramitā'nın on türü bulunmaktadır. Eserde bu türler ayrıntılı olarak açıklanmıştır.

1. Dāna Pāramitā "Sadaka Erdemi" başlığında Dāna-pāramitā'nın "bağış, sadaka, cömertlik ya da verme" anlamlarında olduğu Bodhisattvaların uygulamaları gerekli olan altı pāramitā'dan ya da on pāramitā'dan ilki olduğu ifade edilir. Bu bölümde terimin Budizmde

\footnotetext{
${ }^{1}$ Bundan sonra R-M olarak kisaltılacaktır.
} 
cömertlik tohumlarının geliştirilmesi şeklinde olduğu her şeyin başının iman olduğu dolayısıyla kişinin sadaka vermesi de imana bağlı olduğu anlatılmaktadır. Bodhisattvaların cömert olma yollarından biri de merhametli olmalarıdır. Bodhisattvalar merhamet sayesinde canlılara mal, bilgi ve korkusuzluk sadakası verirler. Budizmde Dāna-pāramitā ile ilgili farklı hikâyeler de anlatılmaktadır. Bunlar şu şekilde sıralanmaktadır: Aç Pars Hikâyesi, Kral Çivi ya da Çibi Hikâyesi, Jīmūtavāhana Hikâyesi, Tavşan Hikâyesi, Viçvantara Hikâyesidir.

2. Śīla Pāramitā "Ahlâkî Davranış Erdemi” başlığında Śīla Pāramitā, "saf ve sakin, temiz, kendini tutma ya da on emir, iyi karakter olarak ifade edilir. Śîla'nın dört durumu temizlik, sakinlik, durgunluk ve sönmek"tir. Genel olarak bu erdem doğru eylemi ifade etmekle birlikte aynı zamanda yeniden doğan canlının ya zengin, mutlu ve huzurlu ya da cennette Tanrılardan biri olarak doğmasını amaçlamaktadır. Günahkârların ise cehennem hayatında ya da hayvan gibi diğer hayat şekillerinden birinde doğmasını sağlar. Budizmdeki üç değer yani vücudu, gönlü ve dili kontrol etme düşüncesi vardır. Sanskritçesinin de verildiği bu eylemler şöyledir: Vücudun yapmış olduğu eylemler; yaşayan hiçbir canlıyı öldürmemek, başkasının malını çalmamak, başkasının karısını arzulamamak, başkasının karısına uzun süre bakmamak. Dilin yapmış olduğu eylemler; yalan söylememek, yalandan uzak durmak, iftiradan uzak durmak, kaba dilden uzak durmak, alaycı ve duygusuz konuşmamak. Gönlün yapmış olduğu eylemler; arzulardan ve kıskançlıklardan uzak durmak, kindarlıktan ve öfkeden uzak durmak, yanlış görüşten uzak durmak. Ayrıca Śīla Pāramitā, üç türlüdür: iyi dharmālara bağlanmak, iyi dharmāları toplamak, kişisel davranışları iyileştirmek, bütün varlıklara fayda sağlamaktır.

3. Kṣānti Pāramitā "Sabır, Tahammül Erdemi” başlığında bu terim "karşıt duruma ve dinî duruma karşı sabır, dayanma, katlanma, tahammül” olarak tanımlanmaktadır. Sıradan ve manevî şeylere karşı soğukkanlılık ve tahammül göstermek, tahammül erdemi, sabır özellikle taşınamayan hakaretlere ve 1stıraplara karşı metanet gösterme olarak ifade edilmektir. Kșānti Pāramitā, üç şekildedir: 1stırap çektiren suçluyu kabul edip anlamak, 1stıraba müsamaha göstermek, dharmāya bağlı kalarak tahammül etmektir.

4. Vīrya Pāramitā "Gayret ya da Enerji Erdemi” başlığında bu terim "enerji, çaba, dayanıklı, dikkatli ve sürekli ilgisi olan, sebatkâr ya da gayretli” tanımlanmaktadır. Vīrya pāramitā üç şekildedir: büyük kararlar almak, günahlarla mücadele etme enerjisi, iyi öğretileri kabul etme, elde etme mücadelesi, bütün duyulu varlıkların refahı için çabalamadır.

5. Dhyāna Pāramitā "Derin Düşünce Erdemi” başlığında bu terim “derin düşünce ya da önsezi anlamına geldiği ifade edilerek yoğunlaşma, trans, düşünme, derin düşünce, etkileyici ve soyut dinsel derin düşünce" gibi anlamları da barındırdığı eklenmiştir. Buradaki amaç kötülüklerden kurtulmaktır. Dhyāna Pāramitā'nın üç türü vardır: samādhi'ye ulaşma dhyānası, 
sıradan ve doğaüstü erdemleri yayma dhyānası, görevlerini başarıyla yerine getirme dhyānasıdır.

6. Prajñā Pāramitā "Bilgi Erdemi” başlığında bu terim bir "Bodhisattva'nın bodhi olma" sözü ve "diğer kıyıdaki bütün varlıkları kurtarma" sözü olarak da ifade edilmektir. Pranidhāna-pāramitānın iki türü vardır. Bunlardan ilki Buddha olma isteği iken ikincisi Bodhisattvaların bütün canlıları kurtarma isteğidir. Bu türler şöyledir: uyanmayı elde etme yemini, bütün canlıların iyiliği ve mutluluğu için edilen yemindir.

7. Upāya Pāramitā "Doğru Yöntem Uygulama Erdemi” başlığında Upāya terimi "uygunluk, şartların uygun olması" gibi anlamlara gelmekte, insanlara bilgi vermeyi ve onların bilgilenmesini sağlamayı kabul etme yöntemi olarak ifade edilmektedir. Upāya Pāramitā iki şekildedir: muhteşem aydınlanma yönünde zihni döndürme ustalığı, bütün canlıları 1stıraplarından kurtarma ve onları koruma ustalığıdır.

8. Praṇidhāna Pāramitā "Bodhi Olma Erdemi” başlı̆̆ında bu terim "arzulamak, istemek anlamındaki terim, bir Bodhisattva'nın bodhi olma sözü ve diğer kıyıdaki bütün varlıkları kurtarma" sözü olarak da ifade edilir. Böylece pranidhāna-pāramitānın iki türü vardır. Bunlardan ilki bodhi yani Buddha olma isteği, ikinci ise Bodhisattvaların bütün canlıları kurtarma isteğidir. $\mathrm{Bu}$ türler şu şekilde sıralanabilir: uyanmayı elde etme yemini, bütün canlıların iyiliği ve mutluluğu için edilen yeminidir.

9. Bala Pāramitā “Güç Erdemi” başlığında bu terim güç, "kuvvet” şeklinde tanımlanır ve "Buddha'nın gücü” olarak anlamlandırılır. Buddha'nın beş gücü ya da on gücü gibi bölümleri bulunmaktadır. Bala Pāramitā’nın iki türü vardır: kendini yetiştirme, eğitme kuvveti ve düşünce, düşünme kuvvetidir.

10. Kṛtyānuṣthhāna-jñāna Pāramitā "Bilgelik Erdemi" başlı̆̆ında bu terim, "hem kendi refahı hem de başkalarının refahı için çalışmayı" ifade etmektedir. On pāramitā'nın sonuncusudur ve erdemi işaret eder. Bilgeliğin iki türü vardır: dharmā mutluluğuna sahip Bodhisattvanın hikmeti ve canlıları manevi olgunluğa ulaştırma hikmetidir.

Erdemlerin anlatıldığı bölümden sonra IV. Kitapta Yer Alan Manzum Parça (s. 1516) başlığına geçilir. Bu bölümde 3242-3301 satırları arasındaki manzum parça Bodhisattva'nın Buddha'yı ve onun öğretisinin övüldüğü bir şiir parçası yer almaktadır. Manzum parçada mısralar arasında bazı yerlerde kafiye ve redif bulunmamaktadır. Tam olarak şiir niteliği taşımasa da 3429-3436 arasında da küçük bir şiir parçası yer almaktadır. 
IV. Kitap Üzerine Yapılan Çalışmalar (s. 16-17) başlı̆̆ında 1913 yılından bugüne eser üzerinde yapılan çalışmalar hakkında kısa bilgi verildikten sonra okuyucuya eser üzerinde yapılan çalışmalarla ilgili toplu bir kaynakça bilgisi sunulmuştur.

Yöntem ve Teknikler (s. 17-19) başlığında yazar eserini oluştururken nasıl bir yol izlediğini belirtmektedir. Bu kısım metnin okunurken daha iyi anlaşılmasını sağlaması açısından oldukça önemli bir bölümdür. $\mathrm{Bu}$ sebeple bu kısmı maddeler halinde sunmak eserin incelenmesinde anlaşılmayı kolaylaştıracağı kanaatindeyiz:

- Yapılan çalışma hem St. Petersburg nüshasına hem de Berlin parçalarına dayanmaktadır. II. bölümde Berlin parçalarının hem yazı çevrimi hem de harf çevrimi, Rashcmann kataloğundaki sıra ile verilmiştir. Rashcmann kataloğunda bulunmayanlar ise Ehlers kataloğuna göre yapılmıştır.

- Berlin parçalarının sağ yanına eğer metin birkaç parçadan oluşuyorsa metnin hangi parçalardan oluştuğu gösterilmiş. Metnin R-M'deki yeri yazılmıştır. Eğer metin tek bir Berlin parçasından oluşmuş ise sadece R-M'deki yeri yazılmıştır.

$$
\begin{aligned}
& \text {... }] \mathrm{b}[\mathrm{o} \text { ärü }] \mathrm{r} \text { altınč }[\ldots \\
& \ldots . . . \mathrm{p}[/ / / / / \mathrm{r} \text { ' ',ltynč }
\end{aligned}
$$

- [St.] Petersburg nüshası 201-344 sayfaları arasında yer almaktadır. Bu sayılardan sonra 0001 olarak başlayan numaralar yazar tarafindan oluşturulan sayılardır. 01 ile başlayan sayılar ise Petersburg nüshasındaki sayfalarda yer alan satır numaralarıdır.

$$
\begin{array}{ll}
000101 & \text { namo buḍdaya } \\
& \text { n'mw pwtd'y } \\
000202 & \text { namo darmaya } \\
\text { n'mw d'rm'y }
\end{array}
$$

- [St.] Petersburg nüshasının hemen sağ yanına metnin Çincesi yazılmıştır ve Çince bölümde 417c20 olarak yazılan kısımlar Taishō' daki yeri ifade etmektedir.

$$
04 \text { altun öylüg y(a)ruk }{ }^{417 c 20} \text { 金光明 }
$$

- [St.] Petersburg nüshasında altı çizilmeyen fakat dipnot hâlinde gösterilenler tek bir kelimeyi, altı çizili olan kelimeler ise birden fazla kelimeyi ifade etmektedir.

- Yazı çevriminde satırlarda düşmüş olan kısımlar [...] işareti ile gösterilmiştir. Bazı kelimelerin harfleri belgede tam olarak okunamıyorsa bunlar italik olarak gösterilmiştir. 
- Metin tamiri yapıldığı bu çalışmada tamiri yapılan yerlerin yazı çevrimi yapılırken, harf sayısı kadar /// işareti kullanılmıştır. Metin parçasında görünen fakat okunmayan harf için de / işareti kullanılmıştır.

- Petersburg nüshasının yazı çevrimi ve harf çevriminden sonra metnin Türkiye Türkçesine aktarımı yapılmıştır.

Şeklinde maddeler hâlinde sunduğumuz çalışma oluşturulurken Ceval Kaya'nın çalışmasından oldukça istifade ettiğini belirten yazar çalışma yöntemini örnekler dâhilinde anlatmakta ve böylece okuyucunun metni anlamasını kolaylaştırmaya çalışmaktadır.

Çalışmanın İşaretler, Kısaltmalar, Kaynakça ve Eser Kısaltmaları bölümlerinden sonra çalışmanın 2. bölümü Berlin Metin Parçaları (s. 27-257) yer almaktadır. Bu bölümde Berlin Belgelerinin Listesi, Berlin Metin Parçalarının Harf çevrimi ve Yazı çevrimi vardır. Altun Yaruk IV. kitap, 6. bölüme ait bu parçaların, Berlin Bilimler akademisinde U olarak kayıtlı olup 196 parça tespit edilebildiğinin ifadesinden sonra bu parçaların tamamı Rashcmann kataloğunda bulunduğu belirtilmektedir. Yazar bu parçaların 180'inin internet ortamında bulunduğunu 16 'sının ise internet ortamında olmadığını söylemektedir. İnternet ortamında bulunmayan bu 16 parça ise *U olarak Raschmann kataloğunun arkasında verilmiştir. Berlin parçalarının 62'sinin Mainz bölümünde olduğu ve bunların da internet ortamında yer aldığı söylenmektedir. Mainz parçalarının tamamını Raschmann, Ehlers kataloğundaki bütün parçaları kitabının arkasında sıralamıştır. Yazar Berlin belgelerinin listesini, Raschmann ve Ehlers katalog numaraları ve metindeki yerleri, Bulunduğu İşaret, Resim Numarası, RM'deki Yeri, Metindeki Satır Numaras1 şeklinde ayrıntılı olarak okuyucuya sunmaktadır.

Çalışmanın 3. bölümü, ST. Petersburg (RM) Asıl Metin (s. 258-466) başlı̆̆ında olup burada metnin Berlin parçaları ile karşılaştırmalı neşri yapılmış ve Petersburg nüshası ile Berlin parçaları arasında farklılıklar varsa dipnotta belirtilmiştir. Böylece metnin kuruluşu daha da sağlam hâle getirilmiştir. Petersburg nüshasında yer alıp da diğer nüshada bulunmayan veya bu nüshada bulunmayıp diğer parçalarda yer alan kelime ve harf farklılıkları gösterilmiştir. Gerekli yerlerde diğer parçalarla karşılaştırılarak ekleme yapılmıştır.

Çalışmanın 4. bölümü, Türkiye Türkçesine Aktarımı (s. 467-506) başlığındadır. Eserin okunması ve karşılaştırmalı metin neşrinden sonraki bölümdür. Bu bölüm çalışmanın belki de en zor kısmıdır. Metnin Türkiye Türkçesine çevirisi doğru anlama ve anlamlandırma ile paralellik gösterir. Fakat IV. Kitapta bir olay örgüsünün bulunmayışı bu durumu oldukça zorlaştırmaktadır. Soyut bir kavram alanını somut bir düzleme aktarıp anlaşılmasını kolaylaştırmaya çalışan yazar, oldukça zor bir işi başarıyla sonuçlandırmıştır. Yazar burada 
paragrafi konu bağlamına göre oluşturmuş ve her bir erdemin özellikleri ve yerleri için ayrı paragraf oluşturularak konu bütünlüğünü sağlamıştır. Buddha'ya saygl, öğretiye saygl, topluluğa saygı ile başlayan eser altınc1 ayın sekizinci günü zhi denilen "tutmak” gün ve rén fare gününde başlayarak yazllıp sekizinci ayın dolunayında on beşinde yazllı tamamladım. Sonrakilere (de) ulaşmış olsun. İyi, güzel. Om supratișthite vajra ye svāhā şeklinde tamamlanmıştır.

Daha sonra metnin Açılamalar (s. 507-642) kısmına geçilmektedir. Bu bölüm çalışmanın 5. bölümüdür. Burada çalışmaya dair notlar yer almaktadır. Yazar bu bölümde [St.] Petersburg nüshasını esas almış ve burada öncelikle satır numaraları yazarak Uygurca ifadelerin yazımı, eğer Çince karşılıkları Taishō'da ${ }^{2}$ varsa Çince ifadeleri yazılmıştır. Daha sonra da tırnak içinde Çince ifadenin Türkçeye çevirisinde yazar Nobel'in Almanca çevirisinden faydalanılarak yaptığını ifade etmektedir. Burada yer alan kelimeler metin bağlamından hareket edilerek sunulmuştur. Kelimelerin anlamsal boyutu ele alınarak kelimelerin terimsel değeri açıklanmıştır. Metin bağlamında kelimelerin anlam ve kavram dünyalarının ele alınıp irdelendiği çalışmadan bazı örnekler vermek söylenileni daha da pekiştireceği kanaatindeyiz: tınl(1)g "canlı" kelimesi, genel olarak evrendeki tüm sezgili canlılar için kullanılan bir ifadedir. Fakat metin bağlamında kelimenin anlamı oldukça değişmektedir. Yazar bu durumu Budizm'de on hayat şekli var olduğunun ve bunların cehennemler, pretalar, hayvanlar, asuralar, insanlar ve Tanrılar âleminden oluşan altı hayat şekli ile diğer dört hayat şekli olan Śrāvakalar, Pretyakabuddhalar, Bodhisattvalar, Buddhalar dünyasından oluştuğunun dolayısıyla tınl(1)g "canlı" sözü, metin bağlamında incelendiğinde altı hayat şekli olan cehennemler, pretalar, hayvanlar, asuralar, insanlar ve Tanrıları karşıladığını ifade etmektedir. Bu açıklama çalışmanın esas kısmının ayrıntılarda ve anlam dünyasında gizli olduğunu göstermektedir. Metinde bilinenin aksine kelimelerin kavram ve anlam dünyalarının çok farklı olduğunu göstermeye çalışan yazar, eserin önemini açıklamalar kısmı ile bir kez daha arttırmaktadır.

Eserin son kısmı olan Dizin bölümünde (s. 643-717) Cibakaya 2, 3. dizin programı kullanılmıştır. Dizinde, metindeki bütün kelimeler ile kelimelerin geçtikleri bütün yerler gösterilmiş, Türkçe olmayan madde başlarının geldikleri diller ve orijinal biçimleri belirtilmiştir.

1913 ’ten bu yana süre gelen Altun Yaruk Sudur çalışmalarının şimdilik sonuncusu Dr. Hacer TOKYÜREK'in kaleminden çıkmıştır. Bu kalem karşılaştırmalı metin neşrinin önemli çalışmalarından biridir. Eseri inşa ederken Çince metinden yararlanan yazar, soyut kavramların

\footnotetext{
${ }^{2}$ http://21dzk.1.u-tokyo.ac.jp/SAT/ddb-bdk-sat2.php?lang=en (T0665_.16.0417c20-T0665_.16.0422b21) 
ağırlıkta olduğu metni somutlaştırıp okuyucunun metni anlamasına oldukça katkıda bulunmuş bunu yaparken de titiz kalemiyle oldukça sistematik bir dizin hazırlamıştır. Bu dizin sayesinde Türkoloji sahasının oldukça önemli bir yerine sahip olan Eski Uygur döneminin söz varlığ gözler önüne serilmiştir. Bundan sonra yapılacak çalışmalara katkı sağlayacağını düşündüğümüz eseri, bilim dünyasına kazandıran yazarı kutluyoruz.

\section{Kaynaklar}

ÖLMEZ, M. (1991). Altun Yaruk III. Kitap (5. Bölüm). Ankara: Türk Dilleri Araştırmaları Dizisi 1.

Mainz 53 ön (http://turfan.bbaw.de/dta/mainz/images/mainz0053_seite1.jpg)

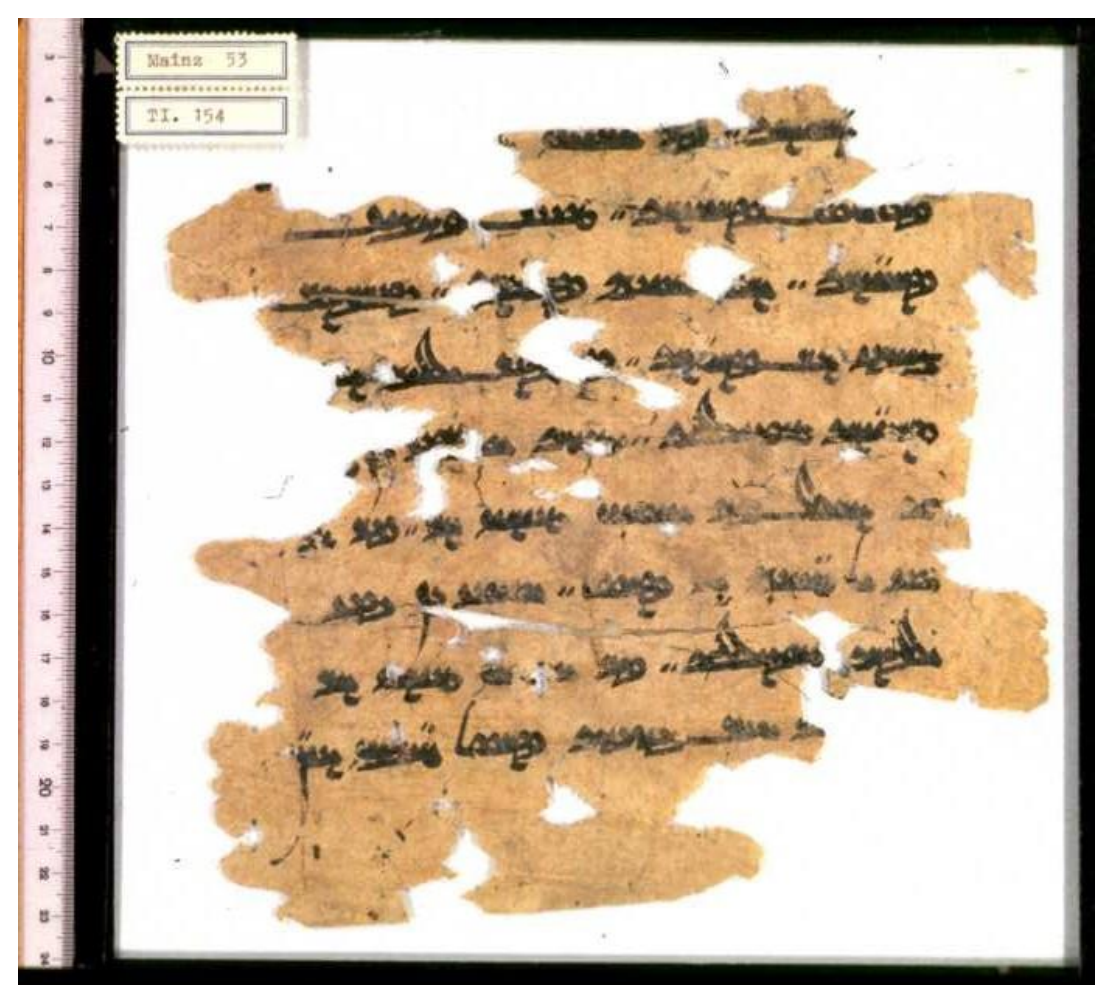

U 605 ön (http://turfan.bbaw.de/dta/u/images/u0605seite1.jpg) 